\title{
Application of multi-sensor advanced DInSAR analysis to severe land subsidence recognition: Alto Guadalentín Basin (Spain)
}

\author{
R. Bonì ${ }^{1}$, G. Herrera ${ }^{2,3,4}$, C. Meisina ${ }^{1}$, D. Notti ${ }^{1,10}$, M. Béjar-Pizarro ${ }^{2,3}$, F. Zucca ${ }^{1}$, P. J. González ${ }^{5}$, \\ M. Palano ${ }^{6}$, R. Tomás ${ }^{7,3}$, J. Fernández ${ }^{8}$, J. A. Fernández-Merodo ${ }^{2,3}$, J. Mulas ${ }^{2,3}$, R. Aragón ${ }^{2,3}$, \\ C. Guardiola-Albert ${ }^{2}$, and O. Mora ${ }^{9}$ \\ ${ }^{1}$ Department of Earth and Environmental Science, University of Pavia, Via Ferrata 1, 27100 Pavia, Italy \\ ${ }^{2}$ Geohazards InSAR laboratory and modeling group, Instituto Geológico y Minero de España (IGME), \\ C/. Alenza 1, 28003 Madrid, Spain \\ ${ }^{3}$ Unidad Asociada de investigación IGME-UA de movimientos del terreno mediante interferometría radar \\ (UNIRAD), Universidad de Alicante, P.O. Box 99, 03080 Alicante, Spain \\ ${ }^{4}$ Earth Observation and Geohazards Expert Group (EOEG), EuroGeoSurveys, the Geological Surveys of \\ Europe, 36-38, Rue Joseph II, 1000 Brussels, Belgium \\ ${ }^{5}$ Institute of Geophysics and Tectonics, School of Earth and Environment, University of Leeds, \\ Leeds, LS2 9JT, UK \\ ${ }^{6}$ INGV Sezione di Catania, Piazza Roma 2, 95123 Catania, Italy \\ ${ }^{7}$ Universidad de Alicante, Dpto. de Ingeniería Civil, Escuela Politécnica Superior de Alicante, P.O. Box 99, \\ 03080 Alicante, Spain \\ ${ }^{8}$ Instituto de Geociencias, UCM-CSIC, Plaza de Ciencias 3, Ciudad Universitaria, 28040 Madrid, Spain \\ ${ }^{9}$ Altamira Information, C/. Còrsega 381-387, 08037 Barcelona, Spain \\ ${ }^{10}$ Departamento de Geodinámica, Universidad de Granada, Avenida Fontenueva, Granada, Spain
}

Correspondence to: R. Bonì (roberta.boni01@universitadipavia.it)

Published: 12 November 2015

\begin{abstract}
Multi-sensor advanced DInSAR analyses have been performed and compared with two GPS station measurements, in order to evaluate the land subsidence evolution in a 20-year period, in the Alto Guadalentín Basin where the highest rate of man-induced subsidence $\left(>10 \mathrm{~cm} \mathrm{yr}^{-1}\right)$ of Europe had been detected. The control mechanisms have been examined comparing the advanced DInSAR data with conditioning and triggering factors (i.e. isobaths of Plio-Quaternary deposits, soft soil thickness and piezometric level).
\end{abstract}

\section{Introduction}

Since the 1960s, the Alto Guadalentín Basin (south-eastern Spain), where the city of Lorca is located, has been affected by severe changes of the groundwater level.

The objectives of this work are (i) to quantify the cumulated displacements over a 20-year period with multi-sensor advanced DInSAR data, and (ii) to investigate the control mechanisms that could explain this land motion.

\section{Study area}

The Alto Guadalentín Basin is located in south-eastern Spain, and it includes an aquifer system that covers an area of about $277 \mathrm{~km}^{2}$, constituted by Plio-Quaternary detrital and alluvial material including clays, sands and conglomerates; Miocene detritical with conglomerate and sand deposits; and locally Triassic carbonate rocks. The Mesozoic metamorphic rocks represent the lower impermeable limit. Since 1960 the agriculture development, triggered uncontrolled aquifer sys- 

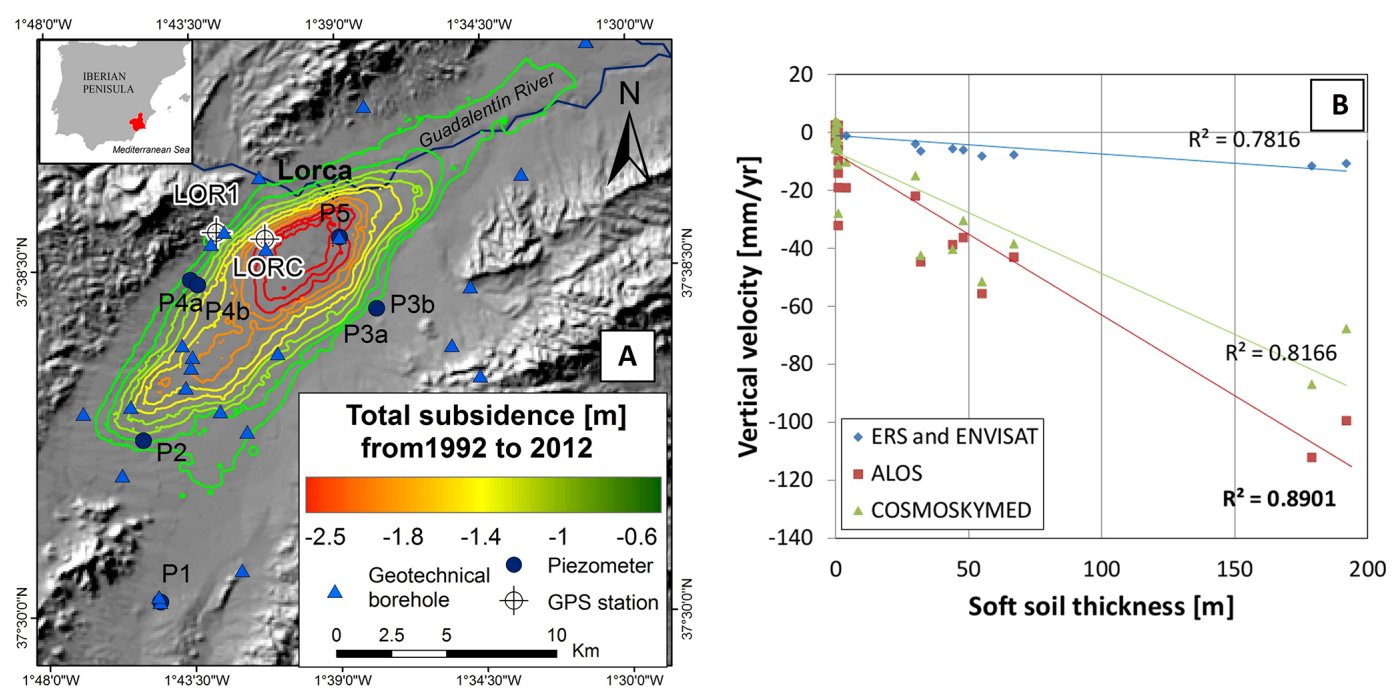

Figure 1. (a) Cumulated displacements (m) of the Alto Guadalentín Basin from 1992 to 2012. (b) Soft soil thickness calculated for each geotechnical boreholes and vertical velocity detected by the different sensors in the proximity of the boreholes. $R^{2}$ stand for Pearson correlation coefficient.

tem exploitation that led it to declare temporarily overexploited in 1987 (CHS, 2006).

\section{SAR dataset and processing details}

A large set of C-band SAR data (ERS-1, ERS-2 and ENVISAT), L-band SAR data (ALOS PALSAR) and X-band SAR data (COSMO-SkyMed) has been employed to reconstruct the temporal and spatial subsidence evolution from 1992 to 2012 that affected the Alto Guadalentín Basin. ERS and ENVISAT-ASAR datasets, covering the 1992-2001 and the 2003-2007 time intervals, respectively, were processed by adopting the Small Baseline approach (Berardino et al., 2002). The ALOS PALSAR dataset from 2007 to 2010 and the COSMO-SkyMed dataset from 2011 to 2012 were processed using the DIAPASON interferometric software and the SPN software (Arnaud et al., 2003) using the Persistent Scatterer approach.

\section{Results}

\subsection{Spatio-temporal evolution}

Note that since the multi-sensors displacement data using different incidence angles (ERS-1/2 and ENVISAT incidence angle permits to detect $92 \%$ of the vertical displacements, whereas ALOS and COSMO-SkyMed satellites measure 83 and $75 \%$ of the vertical displacements, respectively) in order to homogenize the geometrical distortions introduced by the different acquisition angles of the different sensors, both the average velocity and the cumulated surface displacements in the LOS obtained for each dataset have been projected along the vertical direction. In addition, the DInSAR displacement accuracies have been computed at local scale, by comparing them against Global Position System (GPS) measurements. Using continuous records of displacement detected by two GPS stations (LOR1 and LORC) located in a stable and subsiding area, respectively (see the location in Fig. 1a). Average absolute error of $4.6 \pm 4 \mathrm{~mm}$ for the ALOS data and of $4.8 \pm 3.5 \mathrm{~mm}$ for the COSMO-SkyMed data has been detected, confirming the high reliability of the employed DInSAR data. Considering the vertical cumulated surface displacements of the different datasets, the total subsidence from 1992 to 2012 reach up to $2.5 \mathrm{~m}$ with an average subsidence of $1.8 \mathrm{~m}$ over an area of $14.8 \mathrm{~km}^{2}$, located on the central sector of the Alto Guadalentín Basin (Fig. 1a). Subsidence areal extent exhibits a SW-NE elliptical shape parallel to the valley direction.

\subsection{Control mechanisms}

The relationship between the evolution of the groundwater levels and land subsidence is controlled by several factors (geological, hydrogeological and geotechnical factors). These factors can have a direct role in the trigger of subsidence (piezometric level) and others have a conditioning role (lithology and thickness of deformable soil).

\subsubsection{Conditioning factors}

The isobaths map produced by Cerón and Pulido-Bosch (1996), using information from electrical geophysics surveys, represents the variation of the thickness of the PlioQuaternary deposits. A spatial analysis has been performed in order to determine the subsidence related to each isobaths unit. The result of this comparison demonstrates that the 

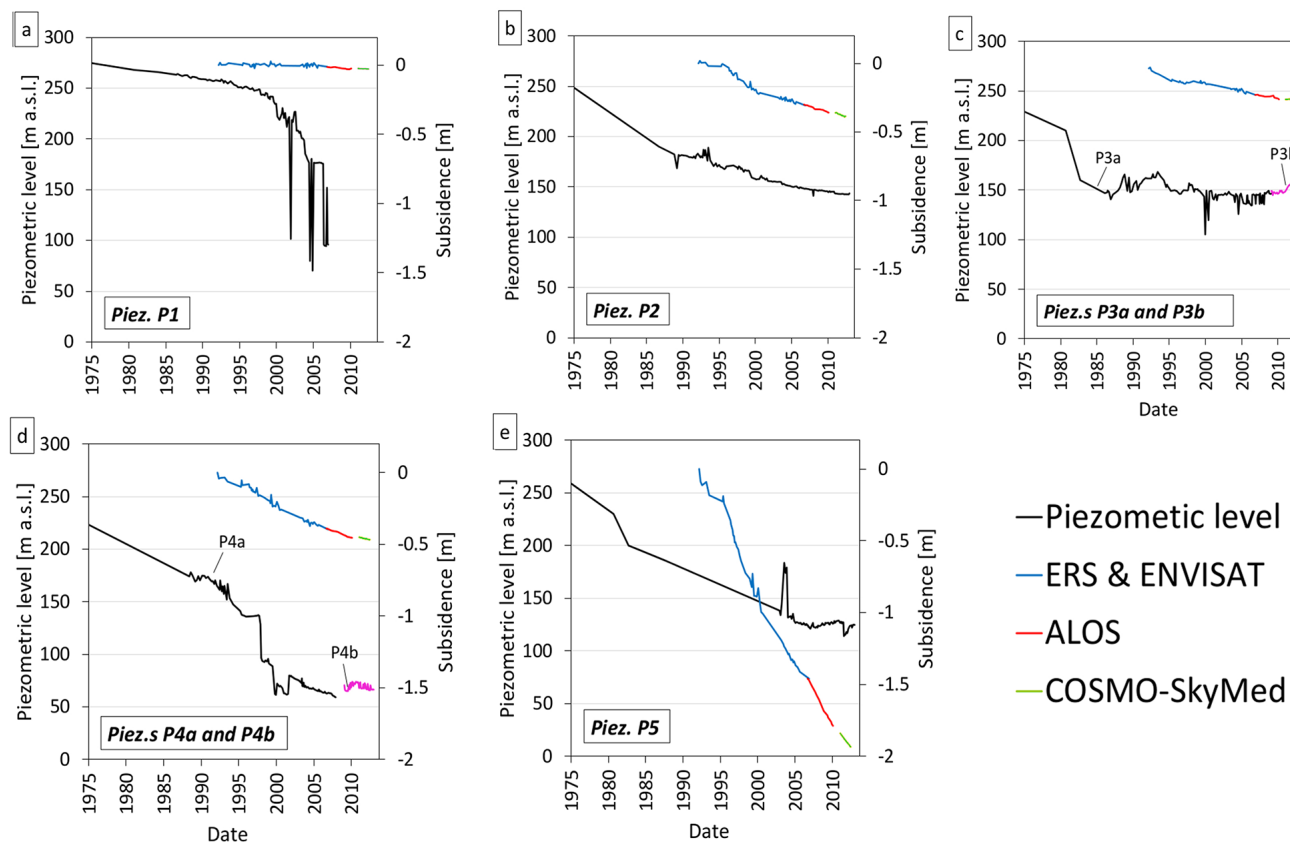

Figure 2. Comparison of the water level variations from 1975 to 2012 (black and pink line) at the different piezometers located on Fig. 1a, and the vertical displacements detected by the satellite sensors (blue, red and green lines).

maximum subsidence does not coincide with the higher value of thickness of Plio-Quaternary filling, so there are other control mechanisms. The Plio-Quaternary deposits contain discontinuous compressible layers and these layers have been selected to analyse the soft soil distribution. Using geotechnical borehole information, soft soils thicker than $100 \mathrm{~m}$ has been detected in the central part of the basin, whereas towards the southwest and bordering areas of the basin thinner soft soils are found. The relationship of soft soil thickness with subsidence rates estimated from the different satellites is straightforward, i.e. maximum subsidence rates are coincident with the thickest soft soils and contrarily, smaller subsidence rates are coincident with the thinnest soft soils found in the bordering areas (Fig. 1b).

\subsubsection{Triggering factor}

A detailed time series analysis of subsidence and ground water evolution is presented for the available (seven) piezometers during the 20-year period (Fig. 2). No correlation is observed at piezometer P1, located in the southern zone, where the highest groundwater drawdown $(162 \mathrm{~m})$ from 1992 to 2007 corresponds to $13 \mathrm{~cm}$ of cumulated subsidence in the period 1992-2012. This is probably due to the lesser amounts of soft soils in the southern border of the basin. Certain correlation is observed in the western part of the basin (piezometers $\mathrm{P} 2, \mathrm{P} 4 \mathrm{a}$ and $\mathrm{P} 4 \mathrm{~b}$ ). The piezometer $\mathrm{P} 2$ displays a steady lowering of the piezometric level from 1989 to 2013 (Fig. 2b) that correlates with the steady subsidence rate. Contrarily piezometers $\mathrm{P} 4 \mathrm{a}-\mathrm{b}$, which are jointly analyzed due to their proximity and characteristics (Fig. 1), exhibit a high ground water level variability that is not in agreement with the estimated subsidence linear rate (Fig. 2d). In the eastern part of the basin, piezometers P3a-b display a water level evolution that is in agreement with subsidence accelerations and decelerations. In the central part of the basin where the thickest soft soils are found (around $190 \mathrm{~m}$ ), the time series of piezometer P5 reveals a groundwater level recovery from 2007 to 2013 that does not correspond with measured subsidence steady rates (Fig. 2e). This fact reveals an inelastic, unrecoverable and permanent deformation of this aquifer as previously reported by González and Fernández (2011) and Rigo et al. (2013), which has been triggered by the groundwater exploitation started in the early 60s. Overall, a clear correlation between groundwater level drawdown and subsidence accelerations or decelerations is not observed.

\section{Conclusions}

This research shows that Advanced DInSAR multi-sensor data obtained from a large set of SAR images are effective in analysing the subsidence spatio-temporal evolution in a 20 -year period over a wide area $\left(277 \mathrm{~km}^{2}\right)$. Moreover, the analysis of the subsidence trend improves the understanding of the apparent response time between the increase of water withdrawals starting from 1960 and the measured subsidence rates. From the analyses we can conclude that the areas where soft soils is thickest, magnitudes of subsidence are greatest, and that the thickness of soft soils plays an im- 
portant role in the time delay between water-level depletion and ground-surface displacement.

Acknowledgements. This work is financially supported by the DORIS project (Ground Deformation Risk Scenarios: an Advanced Assessment Service) funded by the EC-GMES-FP7 initiative (Grant Agreement 423 no. 242212). ALOS PALSAR images were provided by the project JAXA-1209. Part of this work is supported by the Spanish Government under project TEC2011-28201-C02-02 and TIN2014-55413-C2-2-P and by the project 15224/PI/10 from the Regional Agency of Science and Technology in Murcia. Additional funding was obtained from the Spanish Research Program through the projects AYA2010-17448, ESP2013-47780-C2-1-R and ESP2013-47780-C2-2-Rand by the Ministry of Education, Culture and Sport through the project PRX14/00100.

\section{References}

Arnaud, A., Adam, N., Hanssen, R., Inglada, J., Duro, J., Closa, J., and Eineder, M.: ASAR ERS interferometric phase continuity. International Geoscience and Remote Sensing Symposium, 2125 July 2003, Toulouse, France, 2003.
Berardino, P., Fornaro, G., Lanari, R., and Sansosti, E.: A new algorithm for surface deformation monitoring based on small baseline differential SAR interferograms, IEEE T. Geosci. Remote, 40, 2375-2383, 2002.

Cerón, J. C. and Pulido-Bosch, A.: Groundwater problems resulting from $\mathrm{CO}_{2}$ pollution and overexploitation in Alto Guadalentín aquifer (Murcia, Spain), Environ. Geol., 28, 223-228, doi:10.1007/s002540050096, 1996.

CHS: Plan especial ante situaciones de alerta y eventual sequia en la cuenca del Segura: Confederacion hidrografica del Segura, Capitulo 3: Recursos y demandas, p. 5, https://www.chsegura.es/export/descargas/cuenca/sequias/ pes/docsdescarga/Memoria.pdf, 2006.

González, P. J. and Fernández, J.: Drought-driven transient aquifer compaction imaged using multitemporal satellite radar interferometry, Geology, 39, 551-554, doi:10.1130/G31900.1, 2011.

Rigo, A., Béjar-Pizarro, M., and Martínez-Díaz, J.: Monitoring of Guadalentín valley (southern Spain) through a fast SAR Interferometry method, J. Appl. Geophys., 91, 39-48, 2013. 